\title{
Evaluation of an integrated photovoltaic thermal solar (IPVTS) water heating system for various configurations at constant collection temperature
}

\author{
Rajeev Kumar Mishra, ${ }^{1, *}$, G.N.Tiwari ${ }^{1}$ \\ ${ }^{1}$ Centre for Energy Studies, Indian Institute of Technology Delhi, New Delhi, India \\ * Corresponding author. Tel: +91 9717720464, Fax: +91 1126591251,E-mail: bhu.rajeev@gmail.com
}

\begin{abstract}
Photovoltaic thermal (PVT) technology refers to the integration of a PV and a conventional solar thermal collector in a single piece of equipment. In this paper, an integrated photovoltaic thermal solar (IPVTS) water heating system for various configurations has been evaluated for constant collection temperature. Analysis is based on basic energy balance for hybrid flat plate collector in terms of design parameters for a solar water heater installed at Solar Energy Park, IIT Delhi, India and climatic parameters provided by India Meteorological Department Pune, India. It is observed that the daily thermal energy gain of IPVTS system decreases with increasing the constant collection temperature. It is also observed that for collectors partially covered by PV modules, daily thermal energy increases with decrease of collector area co vered by PV module. The exergy analysis of IPVTS system has also been carried out.
\end{abstract}

Keywords: Hybrid PV thermal, Thermal energy, Exergy.

\section{Nomenclature}

A Area......

C Specific heat....

$F^{\prime}$ Flat plate collector efficiency factor...

$F_{R}$ Flow rate factor

$h \quad$ Heat transfer coefficient...

$P F_{1}$ Penalty factor first.

$\mathrm{PF}_{2}$ Penalty factor second.

$I(t)$ Incident solar intensity....

$K \quad$ Thermal conductivity...

Rate of flow of water mass in

collector.

Q 2 Rate of useful energy transfer...

$T$ Temperature....

$U_{t c, a}$ Total heat transfer coefficient from solar cell to ambient through glass cover.

$U_{L, m}$ An overall heat transfer coefficient from blacken surface to ambient...

V Air velocity $\mathrm{kg} / \mathrm{sec}$ ..$k W$

.........m $\mathrm{J} / \mathrm{kg} K$ ..dimensionless dimensionless $\mathrm{W} / \mathrm{m}^{2}$ dimensionless dimensionless ..W/m $\mathrm{m}^{2}$ .. $W / m K$ .$^{o} \mathrm{C}$ $W / m^{2} K$ . W/m $m^{2} K$ $. . m / s$

\begin{tabular}{|c|c|c|}
\hline & bscripts & \\
\hline$A$ & ambient.. & \\
\hline$c$ & solar cell & \\
\hline$f$ & fluid......... & $\ldots \ldots \ldots \ldots \ldots \ldots \ldots \ldots \ldots \ldots \ldots \ldots \ldots \ldots$ \\
\hline$f i$ & inlet fluid... & 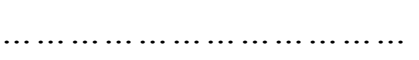 \\
\hline fo & outlet fluid & $\ldots \ldots \ldots \ldots \ldots \ldots \ldots \ldots \ldots \ldots \ldots \ldots \ldots \ldots \ldots$ \\
\hline$g$ & glass .......... & 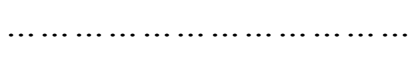 \\
\hline & module & 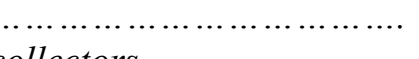 \\
\hline
\end{tabular}

\section{Greek letters}

$\alpha$ absorptivity..-

$(\alpha \tau)_{\text {effproduct of effective. }}$

$\beta$ packing factor.

$\eta_{i}$ an instantaneous

$\tau$ transmittivity

\section{Introduction}

Photovoltaic thermal (PVT) technology refers to the integration of a photovoltaic (PV) module and a conventional solar thermal collector in a single piece of equipment. The reason behind the hybrid concept is that more than $80 \%$ of the solar radiation falling on PV cells is either reflected or converted to thermal energy. This leads to an increase in the PV cell's 
working temperature as much as $40-50^{\circ} \mathrm{C}$ above the ambient temperature. Because of this temperature increase there can be two undesirable consequences: (i) $0.3 \%$ to $0.6 \%$ of efficiency loss per degree $\mathrm{C}$ rise in PV cell temperature and (ii) a permanent damage in the structure of PV module if the thermal stress remains for a long period of time. In applications of PVT system, the production of electricity is the main priority, and therefore, it is necessary to operate the PV modules at low temperature in order to keep the PV cell electrical efficiency at a sufficient level. The temperature of the PV module in the hybrid PVT system can be reduced by cooling the base of PV module by allowing water/air to flow below it (Prakash [1], Tripanagnostopoulos et al. [2], Zondag et al. [3], Jones and Underwood [4], Chow [5], and Infield et al. [6]). Thermal energy available from PV module can be used for many applications namely water and air heating for domestic, agricultural sectors and buildings for thermal heating/cooling.

In this paper, the performance of the $\mathrm{N}$ collectors connected in series is evaluated by considering the three different cases, namely: Case A: All the collectors are fully covered by glass and connected in series. Case B: All collectors are partially covered by PV modules and connected in series and Case C: All the collectors are fully covered by PV module (glass to glass) and connected in series.

\section{Methodology}

For the present study conventional tube-in-plate-type collector of area of $2 \mathrm{~m}^{2}$ is considered. The design parameters of photovoltaic thermal (PVT) collectors are shown in Table 1. The glazing surface of the collector is either glass or PV module depending upon the requirement of the user. To increase the absorption of solar radiation the absorber plate of collector is blackened by black paint.

\section{Energy balance equations:}

In order to write the energy balance equation of PVT solar water collectors connected in series, the following assumptions have been made:

- One dimensional heat conduction is good approximation for the present study.

- The specific heat of water remains constant. It does not change with rise in temperature of water.

- The system is in quasi-steady state.

- The ohmic losses in the solar cell and PV module are negligible.

Energy balance for solar cells of PV module (glass-glass),

$$
\alpha_{c} \tau_{g} \beta_{c} I(t) W d x=\left[U_{t c, a}\left(T_{c}-T_{a}\right)+h_{c, p}\left(T_{c}-T_{p}\right)\right] W d x+\eta_{c} \beta_{c} I(t) \cdot W d x
$$

From Eq.(1) the expression fro cell temperature is

$$
T_{c}=\frac{(\alpha \tau)_{1, \text { eff }} I(t)+U_{t c, a} T_{a}+h_{c, p} T_{p}}{U_{t c, a}+h_{c, p}}
$$

Energy balance for blackened absorber plate below the PV module,

$$
\alpha_{p}\left(1-\beta_{c}\right) \tau_{g}^{2} I(t) W d x+h_{c, p}\left(T_{c}-T_{p}\right) W d x=h_{p, f}\left(T_{p}-T_{f}\right) W d x
$$

From Eq. (3), the expression for plate temperature is

$$
T_{p}=\frac{(\alpha \tau)_{2, e f f} I(t)+P F_{1}(\alpha \tau)_{1, e f f} I(t)+U_{L 1} T_{a}+h_{p, f} T_{f}}{U_{L 1}+h_{p, f}}
$$


Energy balance for water flowing through an absorber pipe below the PV module,

$$
\dot{m}_{f} C_{f} \frac{d T_{f}}{d x} d x=F^{\prime} h_{p, f}\left(T_{p}-T_{f}\right) W d x
$$

In the present study three different configurations of PVT solar water collectors have been considered

Case A: All collectors are fully covered by glass and connected is series:

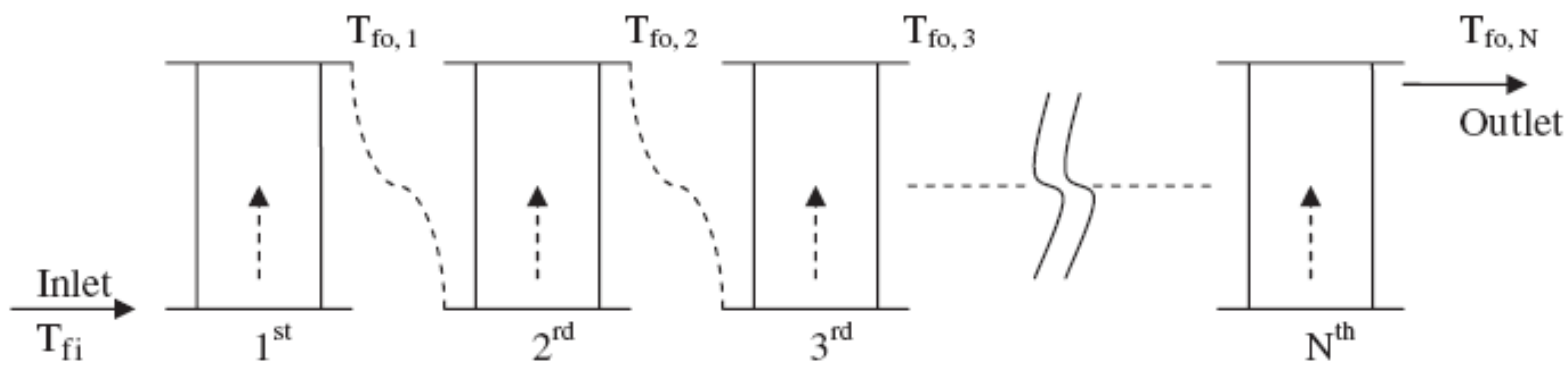

Fig. 1. Collectors fully covered by glass and connection in series.

Following Duffie and Beckman [7] and Tiwari [8] the mass flow rate for $\mathrm{N}$ collectors connected in series can be obtained as:

$$
\dot{m}_{f}=\frac{F^{\prime} N A_{c} U_{L, c}}{C_{f}\left[\log \left\{T_{f i}-\left(\frac{(\alpha \tau)_{c, e f f} I(t)}{U_{L, c}}+T_{a}\right)\right\}-\log \left\{T_{f o N}-\left(\frac{(\alpha \tau)_{c, e f f} I(t)}{U_{L, c}}+T_{a}\right)\right\}\right]}
$$

Case B: The collectors are partially covered by PV modules and connected in series

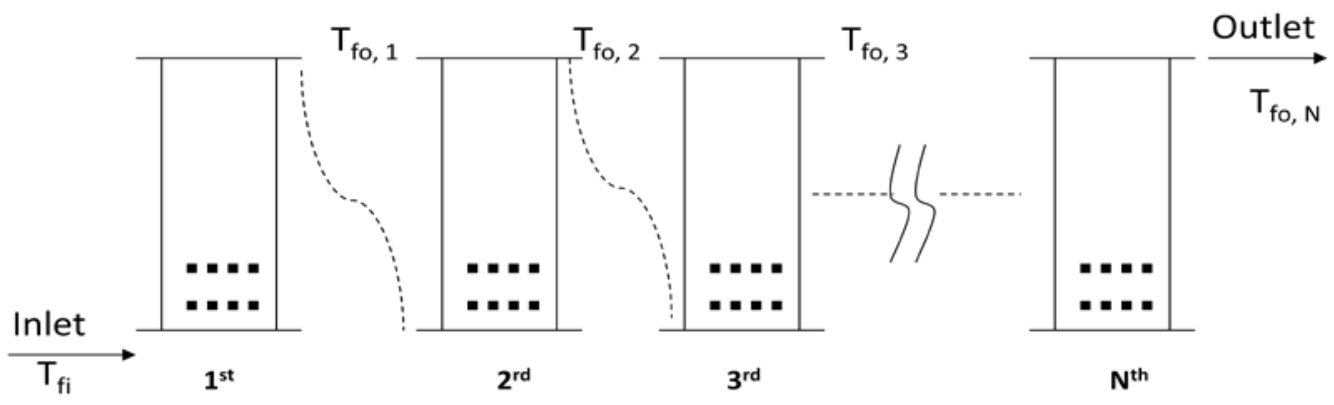

Fig. 2. Collectors partially covered by PV module and connected in series.

Following Dubey and Tiwari [9] the outlet water from $\mathrm{N}$ such collectors connected in series can be given as:

$T_{f o N}=\frac{\left(A F_{R}(\alpha \tau)\right)_{1}}{\dot{m}_{f} C_{f}}\left(\frac{1-K_{K}{ }^{N}}{1-K_{K}}\right) I(t)+\frac{\left(A F_{R} U_{L}\right)_{1}}{\dot{m}_{f} C_{f}}\left(\frac{1-K_{K}{ }^{N}}{1-K_{K}}\right) T_{a}+T_{f i} K_{K}{ }^{N}$

where, 


$$
\begin{aligned}
& K_{K}=\left[1-\frac{\left(A F_{R} U_{L}\right)_{1}}{\dot{m}_{f} C_{f}}\right] \\
& \left(A F_{R}(\alpha \tau)\right)_{1}=\left[A_{m} F_{R m} P F_{2}(\alpha \tau)_{m, e f f}\left(1-\frac{A_{c} F_{R c} U_{L, c}}{\dot{m}_{f} C_{f}}\right)+A_{c} F_{R c}(\alpha \tau)_{c, e f f}\right]
\end{aligned}
$$

and

$$
\left(A F_{R} U_{L}\right)_{1}=\left[A_{m} F_{R m} U_{L, m}\left(1-\frac{A_{c} F_{R c} U_{L, c}}{\dot{m}_{f} C_{f}}\right)+A_{c} F_{R c} U_{L, c}\right]
$$

Case C: All the collectors are fully covered by glass to glass type PV module and connected in series

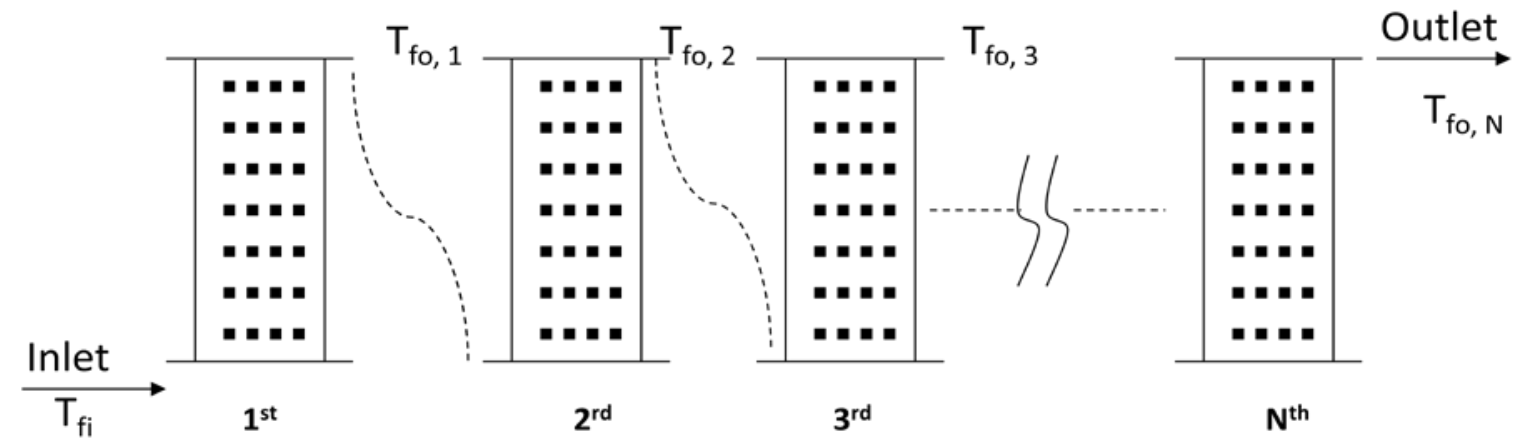

Fig.3. Collectors fully covered by PV modules and connected in series.

Following Dubey and Tiwari [9] Mass flow rate for N collectors partially covered with PV modules connected in series can be obtained as,

$$
\dot{m}_{f}=\frac{N F^{\prime} A_{m} U_{L, m}}{C_{f}\left[\log \left\{T_{f i}-\left(\frac{P F_{2}(\alpha \tau)_{m, e f f} I(t)}{U_{L, m}}+T_{a}\right)\right\}-\log \left\{T_{f o N}-\left(\frac{P F_{2}(\alpha \tau)_{m, e f f} I(t)}{U_{L, m}}+T_{a}\right)\right\}\right]}
$$

The rate of useful thermal energy obtained from $\mathrm{N}$ identical collectors connected in series can be given as

$$
\dot{Q}_{u}=\dot{m}_{f} C_{f}\left(T_{f o N}-T_{a}\right)
$$

Electrical Efficiency of solar cell depends on solar cell temperature and can be given by Evans [10] and Schott [11]

$$
\eta_{c}=\eta_{o}\left[1-\beta_{o}\left(\overline{T_{c}}-T_{o}\right)\right]
$$


Table 1. Design parameters of photovoltaic thermal (PV/T) collector

\begin{tabular}{llcl}
\hline Parameters & Values & Parameters & \multicolumn{2}{c}{ Values } \\
\hline $\mathrm{A}_{\mathrm{C}}$ & $2.0 \mathrm{~m}^{2}$ & $\mathrm{U}_{\mathrm{LC}}$ & $3.0 \mathrm{~W} / \mathrm{m}^{20} \mathrm{C}$ \\
$\mathrm{A}_{\mathrm{m}}$ & $0.605 \mathrm{~m}^{2}$ & $\mathrm{U}_{\mathrm{Lm}}$ & 3.44 \\
& & & \\
$\mathrm{C}_{\mathrm{f}}$ & $\mathrm{m}^{20} \mathrm{C}$ & $\mathrm{U}_{\mathrm{tc}, \mathrm{a}}$ & $9.5 \mathrm{~W} / \mathrm{m}^{20} \mathrm{C}$ \\
$\mathrm{F}^{\prime}$ & $4190 \mathrm{~J} / \mathrm{kgK}$ & $\mathrm{V}$ & $1.0 \mathrm{~m} / \mathrm{s}$ \\
$\mathrm{F}_{\mathrm{Rc} 1}$ & 0.968 & $\mathrm{~W}$ & $0.125 \mathrm{~m}$ \\
$\mathrm{~F}_{\mathrm{Rc} 2}$ & 0.95 & $\alpha_{\mathrm{c}}$ & 0.90 \\
$\mathrm{~F}_{\mathrm{Rm}}$ & 0.94 & $\tau_{\mathrm{c}}$ & 0.95 \\
$\mathrm{~h}_{\mathrm{c}, \mathrm{p}}$ & 0.96 & $\beta_{\mathrm{c}}$ & 0.89 \\
$\mathrm{~h}_{\mathrm{p}, \mathrm{f}}$ & $5.7 \mathrm{~W} / \mathrm{m}^{2}$ & $\eta_{\mathrm{o}}$ & 0.12 \\
$\mathrm{PF}_{1}$ & $100 \mathrm{~W} / \mathrm{m}^{2}$ & $\alpha_{\mathrm{p}}$ & 0.80 \\
$\mathrm{PF}_{2}$ & 0.357 & $\tau_{\mathrm{g}}$ & 095 \\
$\mathrm{~K}$ & 0.965 & & \\
$\dot{m}$ & $204 \mathrm{~W} / \mathrm{m}^{\circ} \mathrm{C}$ & & \\
\hline
\end{tabular}

\section{Result and Discussions}

The variation of solar intensity and ambient temperature for a typical day in the summer month (January) is shown in Figure 4. The values of design parameters of flat plate collector are given in Table 1. Here, the results of the three cases, case A (fully covered by glass) and case B (partially covered by PV modules) and case C (fully covered by PV modules) are discussed in detail. Equations 6,7 a nd 8 have been computed using MATLAB software for evaluating the mass flow rate at different outlet water temperatures for a typical day during the month of January for a given design and climatic parameters (Table 1). Figures 5a and 5b represent the hourly variation of mass flow rate for case A and case B respectively at various constant outlet temperatures. The result shows that for constant collection temperatures 30 $60^{\circ} \mathrm{C}$ the mass flow rate of water in tubes decreases from $0.1-0.01 \mathrm{~kg} / \mathrm{s}$ in case $\mathrm{A}, 0.08-0.01$ $\mathrm{kg} / \mathrm{s}$ in case B. Figure $5 \mathrm{c}$ gives the hourly variation of mass flow rate for case C. Figure shows that in this case one cannot get the outlet water temperature more than $40^{\circ} \mathrm{C}$ in January month and the mass flow rate decreases from 0.04 to $0.01 \mathrm{~kg} / \mathrm{s}$ for case $\mathrm{C}$.

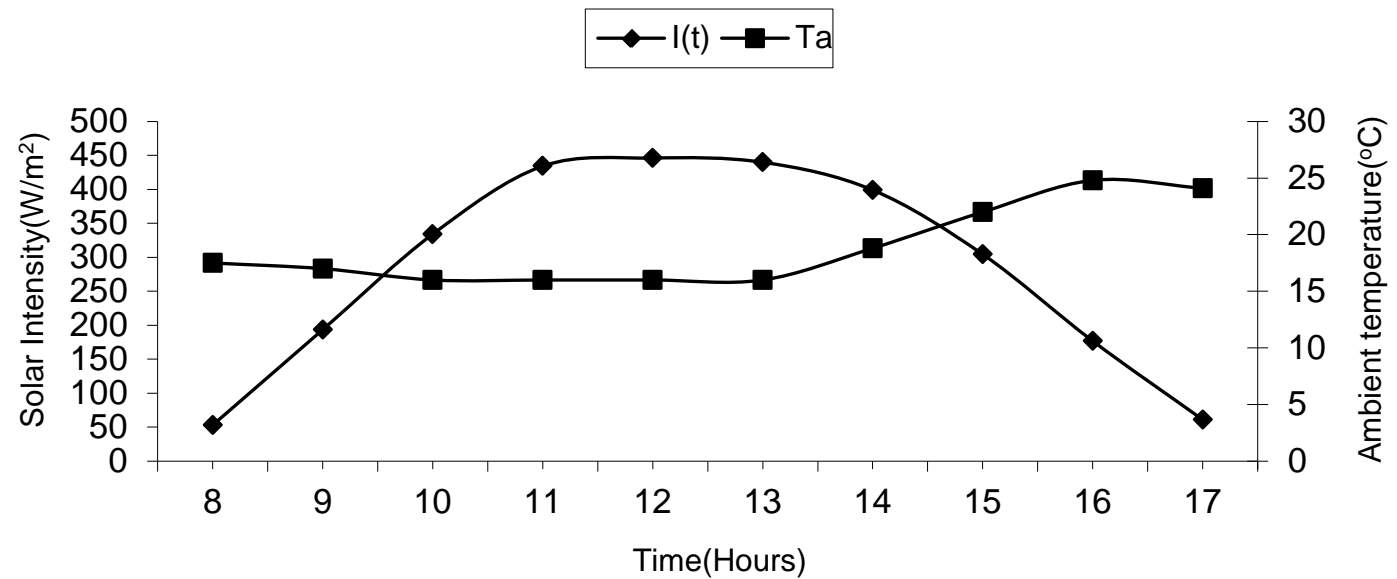

Fig. 4. Hourly variation of solar intensity and ambient temperature of a typical day in the month of January. 


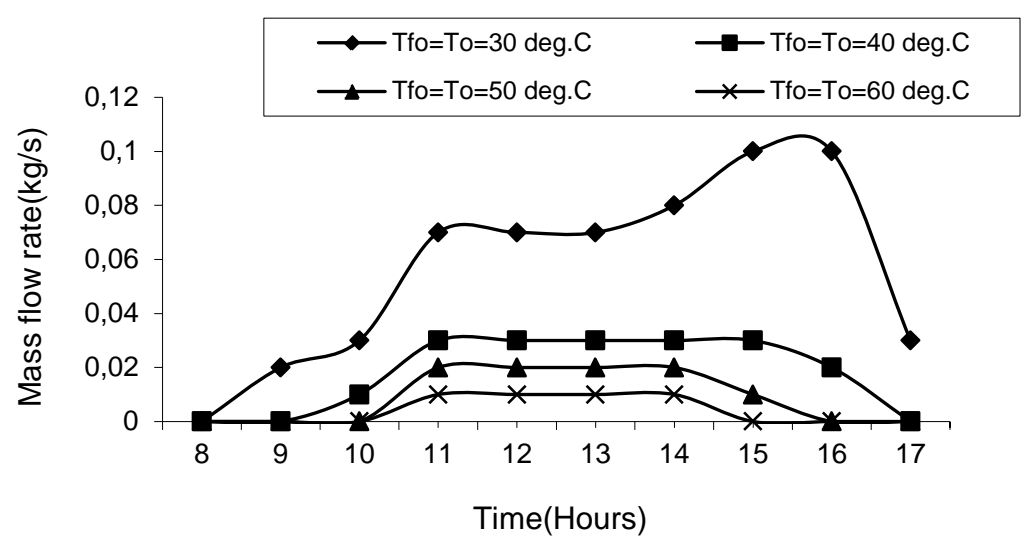

Fig. 5a. Hourly variation of mass flow rate at different outlet temperature for case A.

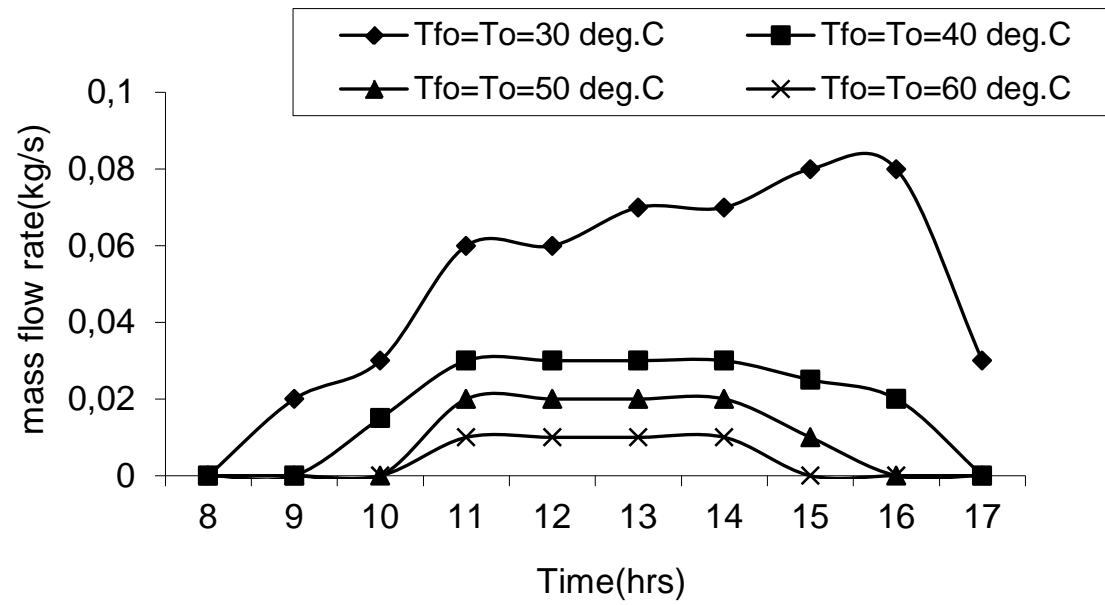

Fig. 5b. Hourly variation of mass flow rate at different outlet temperature for case B.

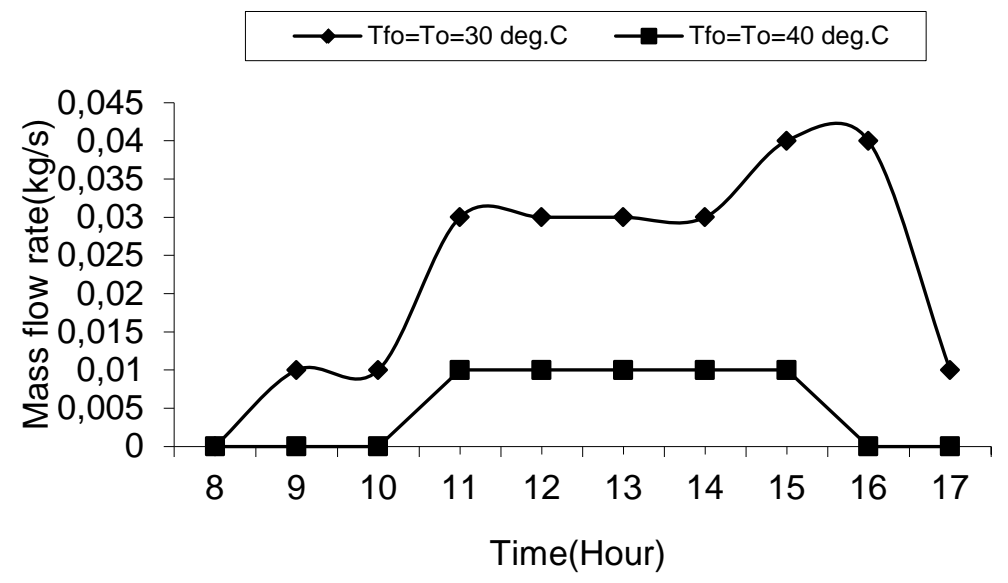

Fig. 5c. Hourly variation of mass flow rate at different outlet temperature for case $C$.

Fig. $6 \mathrm{a}$ and $6 \mathrm{~b}$ represent the hourly variation of thermal energy gain and electrical energy gain respectively for various configurations of PVT collectors. The figures show that as the 
collector area covered by PV modules increases the thermal energy gain decreases whereas the electrical energy gain increases as the collector area covered by PV modules increases.

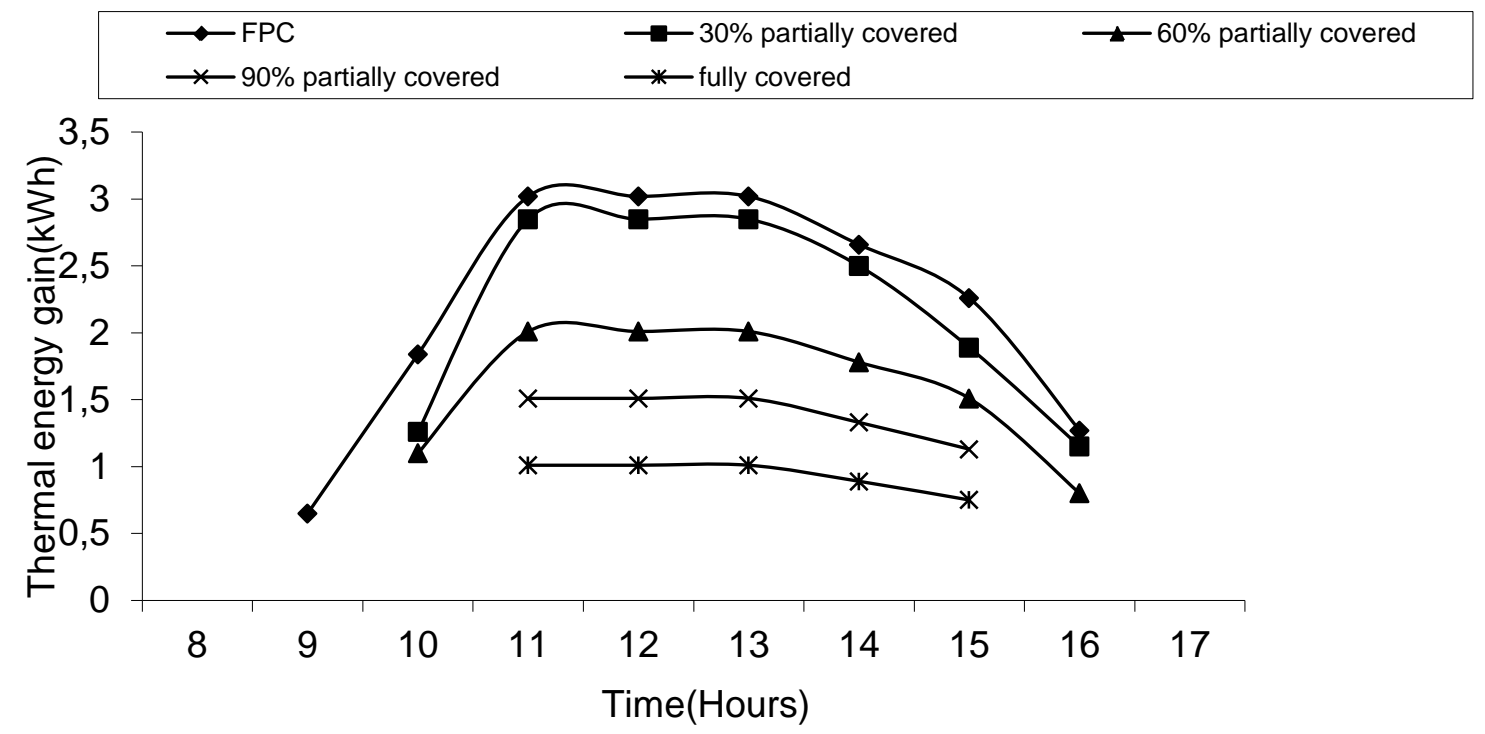

Fig. 6a. Hourly variation of thermal energy gain for different configuration.

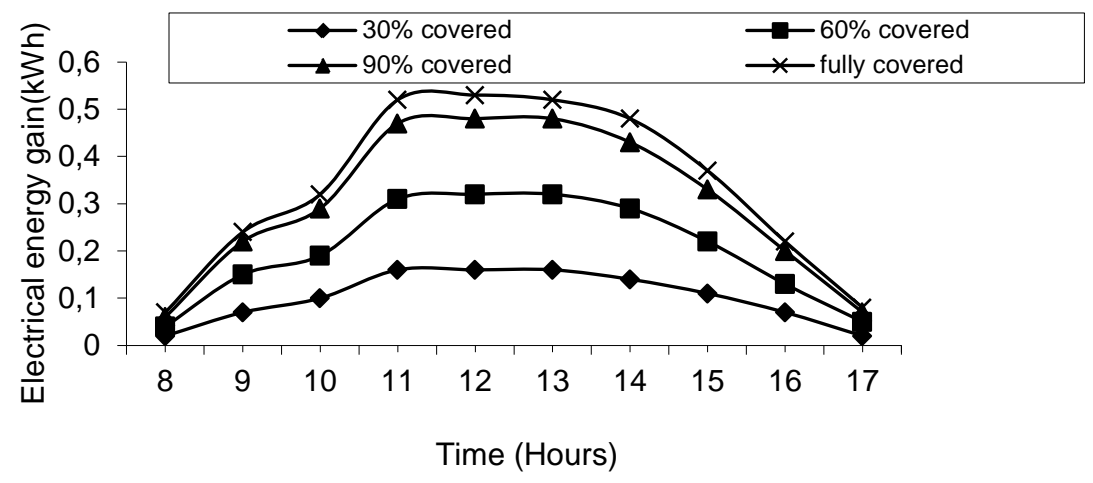

Fig. 6b. Hourly variation of electrical energy gain for different configurations.

\section{Conclusion}

The maximum thermal energy gain is obtained when collectors fully covered by glass cover; however maximum electrical energy gain is obtained when collectors are fully covered by PV modules.

\section{References}

[1] Prakash, J., Transient analysis of a photovoltaic-thermal solar collector for co- generation of electricity and hot air/water. Energy Conversion and Management. 35, 1994 pp. 967 972.

[2] Tripanagnostopoulos, Y., Hybrid photovoltaic/thermal solar system, Solar Energy 72(3), 2002, pp. 217-234.

[3] Zondag, H.A., de Vries, D.W. de, van Helden, W.G.J. ,van Zolengen, R.J.C., Steenhoven, A.A., The thermal and electrical yield of a P V-thermal collector. Solar Energy 72 (2), 2002, pp. 113-128. 
[4] Jones, A.D., Underwood, C.P., A thermal model for photovoltaic systems. Solar Energy 70 (4), 2001, pp. 349-359.

[5] Chow, T.T., Performance analysis of photovoltaic-thermal collector by explicit dynamic model. Solar Energy 75, 2003, pp.143-152.

[6] Infield, D., Mei, L., Eicker, U., Thermal performance estimation of ventilated PV facades, Solar Energy, 76(1-3), 2004, pp. 93-98.

[7] Duffie, J.A., Beckman, W.A., 1991. Solar Engineering of Thermal Processes. John Wiley and Sons, New York.

[8] Tiwari, G.N., Solar Energy: Fundamentals, Design, Modeling and Applications. Narosa Publishing House, New Delhi, 2004.

[9] Dubey, S. and Tiwari, G.N., Analysis of different configurations of flat plate collectors connected in series, International Journal of Energy Research, 32, 2008, pp. 1362-1372.

[10]Evans, D.L., Simplified method for predicting PV array output. Solar Energy 27, 1981, pp. 555-560.

[11] Schott, T., Operational temperatures of PV modules. In: Proceedings of $6^{\text {th }} \mathrm{PV}$ Solar Energy Conference, 1985, pp. 392-396. 